\title{
Ecology and diversity of freshwater shrimps in Banco National Park, Côte d'Ivoire (Banco River Basin)
}

\author{
I.A. Camara ${ }^{(1)}$, M.K. Konan ${ }^{(1)}$, D. Diomandé(1), E.O. Edia ${ }^{(1)}$, G. Gourène ${ }^{(1)}$
}

Received October 16, 2009 / Reçu le 16 octobre 2009

Revised November 27, 2009 / Révisé le 27 novembre 2009

Accepted November 30, 2009 / Accepté le 30 novembre 2009

Key-words:
ecology,
diversity,
freshwater
shrimps,
Banco River
Basin,
Banco National
Park,
Côte d'Ivoire

\section{ABSTRACT}

Shrimps are an important component of river invertebrate assemblages in tropical freshwater where they are a controlling group in food webs. In order to determine shrimp diversity in the Banco Basin (Côte d'Ivoire, West Africa) and examine whether the patterns of species distribution were related to environmental conditions, six sites were monitored. Sampling was conducted in 2008 during February, May, September and November using a long-handled net (25-cm diameter, 2-mm mesh). For each site, we measured environmental variables (conductivity, $\mathrm{pH}$, water temperature, dissolved oxygen, turbidity, current speed, and water depth and width). Three shrimp species, Macrobrachium thysi (Powell 1980), Macrobrachium dux (Lenz 1910) and Desmocaris trispinosa (Aurivillius 1898) were identified. $D$. trispinosa was the largest distributed (more than $50 \%$ of occurrence) and the most abundant (67\% of total number of specimens caught). It was followed by $M$. thysi with $47 \%$ and $32 \%$ of occurrence and abundance, respectively. Canonical correspondence analysis (CCA) showed a spatial distribution of the shrimp community, significantly influenced by width, depth, conductivity, type of substrate, turbidity and dissolved oxygen. Due to the fact that the Banco River hosts an endemic species in Côte d'Ivoire (Macrobrachium thysi), the conservation of integrity of this basin was recommended.

\section{RÉSUMÉ}

\section{Écologie et diversité des crevettes d'eau douce dans le Parc National du Banco (Bassin du Banco, Côte d'Ivoire)}

Mots-clés : écologie, diversité, crevettes d'eau douce, bassin de la rivière Banco, Parc National du Banco, Côte d'Ivoire
Les crevettes ont un rôle très important dans la chaîne trophique des eaux douces. La diversité des crevettes et leurs relations avec les paramètres environnementaux ont été étudiées dans le bassin du Banco (Côte d'Ivoire, Afrique de l'Ouest). Les crevettes ont été échantillonnées mensuellement pendant quatre mois en 2008 (février, mai, septembre et novembre) à l'aide d'une épuisette $(25 \mathrm{~cm}$ de diamètre, $2 \mathrm{~mm}$ de maille). À chaque échantillonnage, des paramètres environnementaux ont été évalués. Trois espèces de crevettes ont été capturées : Macrobrachium thysi (Powell 1980), M. dux (Lenz 1910) et Desmocaris trispinosa (Aurivillius 1898). L'espèce $D$. trispinosa est la plus largement distribuée (plus de $50 \%$ d'occurrence) et la plus abondante ( $67 \%$ d'abondance relative). Elle est suivie de $M$. thysi avec une occurrence et une abondance respectives de $47 \%$ et $32 \%$. L'analyse

(1) Laboratoire d'Environnement et de Biologie Aquatique, UFR-Sciences et Gestion de l'Environnement, Université d'Abobo-Adjamé, 02 BP 801 Abidjan 02, Côte d'Ivoire, camadams80@yahoo.fr 
canonique des correspondances montre que la distribution spatiale des crevettes dans le bassin du Banco est fortement influencée par la largeur, la profondeur, la conductivité, le type de substrat, la turbidité et l'oxygène dissous. Compte tenu du fait que la rivière Banco héberge une espèce endémique à la Côte d'Ivoire (Macrobrachium thysi), la conservation de l'intégrité de ce bassin est fortement recommandée.

\section{INTRODUCTION}

Shrimps are critical species in stream food webs because they serve as intermediate consumers, linking production of periphyton and detritus with higher trophic groups (Browder et al., 1994; Frederick and Spalding, 1994). Yet the shrimps represent an important food resource for carnivorous fishes (Resende et al., 1996). The Banco National Park (BNP) is located in the middle of Abidjan, the economic capital of Côte d'Ivoire. This park, founded in 1953, is a tropical rain forest with primary relicts of evergreen forest (Hall and Swaine, 1981; Parren and De Graaf, 1995). The Banco River situated in this park is subjected to anthropogenic disturbance due to sewage draining by canals coming from the neighbouring cities of BNP. This disturbance represents a menace for the river integrity and the aquatic communities. Despite the conservation role of BNP, few studies (Daget et Iltis, 1965; Powell, 1980) have been devoted to aquatic fauna. Concerning shrimps, the only literature concerns the description of Macrobrachium thysi by Powell (1980). To our knowledge, no study, so far, has dealt with diversity and ecological requirements of shrimp of this river.

The objectives of this study are (i) to present a comparative account of the physicochemical parameters, and the density and wet biomass of the shrimps between upstream and downstream stations of the Banco River channel and the permanent pool stations, and (ii) to investigate the relationships between shrimp density and environmental parameters of the Banco River Basin.

\section{MATERIALS AND METHODS}

\section{> STUDY AREA AND SAMPLING STATIONS}

The Banco River Basin (approximately $9 \mathrm{~km}$ ) is located between $5^{\circ} 21^{\prime}-5^{\circ} 25^{\prime} \mathrm{N}$ and $4^{\circ} 01^{\prime}-4^{\circ} 05^{\prime} \mathrm{W}$ in the BNP (3000 ha) (Figure 1). The climate of the BNP is typical of equatorial rain forest, comprising four seasons (Girard et al., 1971): a long dry season (December to March), a long rainy season (April to July), a low dry season (August to September) and a low rainy season (October to November).

Sampling was conducted in 2008 during February, May, September and November. Six sampling stations were selected and each was sampled once in each sampled month. Four sites (S1, S2, S3 and S5) were situated along the main river channel, while the other two (S4 and S6) were permanent pools. Stations S1 and S2 were located in the upstream and were commonly characterised by clean water, and the presence of fragmented leaves, woody debris, riparian vegetation (Turraenthus africanus, Petersianthus macrocarpus and Dacryodes klaineana) and macrophyte flora (Thaumatococcus daniellii), with a sandy-silty substratum. In the midstream station (S3), the water was cloudy, smelly, and likely to contain a lot of suspended matter due to arrival of waste water. The substratum in S3 was mainly sand and lacking in riparian vegetation. Musanga cecropioides and Xanthosoma sp. were the marginal vegetations found at this station. At the downstream station (S5), banks were well defined with marginal grassy vegetation (Cyclosorus striatus and Nephrolepis biserrata). The river bed was rocky to sandy with cloudy water. Water was clear (S4) to dark (S6) in the permanent pool stations. These sites were defined by an abundance of roots and large quantities of plant detritus with a sandy to silty bed and high vegetation coverage. The station S6 was covered by Indian bamboo trees (Bambusa sp.). 


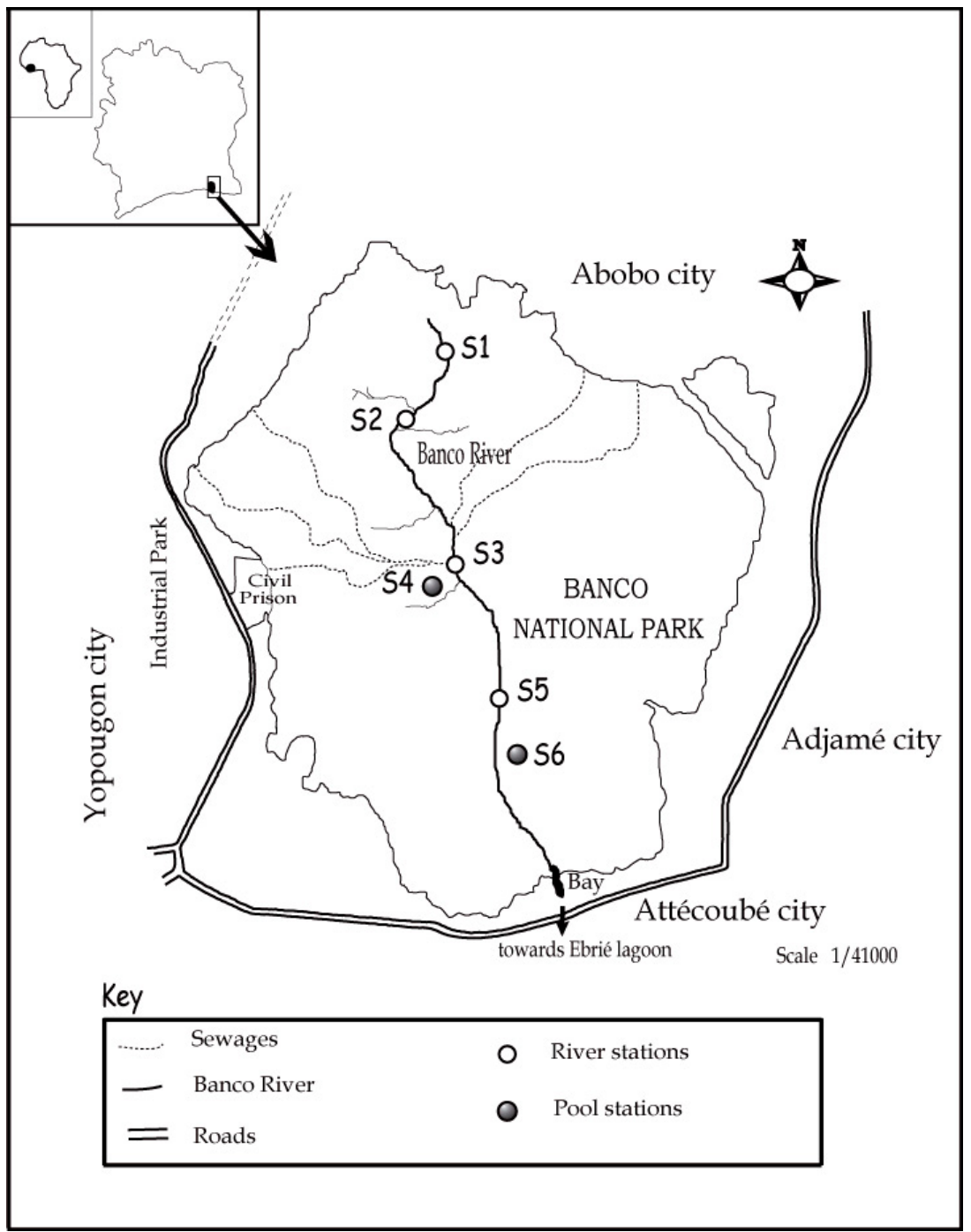

\section{Figure 1}

Map of the Banco National Park showing the study stations.

\section{Figure 1 \\ Carte du Parc national Banco situant les stations d'étude.}

\section{> ENVIRONMENTAL VARIABLES}

Thirteen environmental variables were used to describe habitat conditions at each sampling site. Measurements of all variables were made in situ between $7 \mathrm{~h}$ and $12 \mathrm{~h}$ before shrimp sampling. Conductivity $\left(\mu \mathrm{S} \cdot \mathrm{cm}^{-1}\right)$, water temperature $\left({ }^{\circ} \mathrm{C}\right)$, dissolved oxygen $\left(\mathrm{mg} \cdot \mathrm{L}^{-1}\right)$ and $\mathrm{pH}$ were measured using a multiparameter apparatus (WTW 840i). Turbidity (NTU) was measured using a turbidimeter (AQUA LYTIC CD 24). The habitat variables included current velocity $\left(\mathrm{m} \cdot \mathrm{S}^{-1}\right)$, which was taken in mid-channel on five occasions by timing a floating object (polystyrene cube) over a five-metre stretch of the river. The value of current velocity was the average of the five trials. Water depth $(\mathrm{m})$ and width $(\mathrm{m})$ were measured (average of five trials) to the nearest centimetre using a decametre. Canopy cover (\%), substrate type (mud, sand, gravel), and woody debris (\%) were estimated visually at each sampling site as described by Gordon et al. (1994), and Rios and Bailey (2006). 


\section{> SHRIMP COLLECTION AND IDENTIFICATION}

Shrimps were collected using a long-handled net (25-cm diameter, 2-mm mesh). Four samples were obtained at each site during the sampling period. The material retained in the net was transferred to a white tray, and all shrimp individuals were sorted, placed in plastic bottles and preserved with $70 \%$ ethanol. In the laboratory, the shrimps were sieved by using a $0.5-\mathrm{mm}$ sieve sorted into a Petri dish. All specimens caught were identified under a stereomicroscope according to Monod (1966, 1980) and Powell (1980), counted, and weighed.

\section{> DATA ANALYSES}

The number of individuals per species obtained in the sample depends on the space of time of the sampling. We standardised all data by conversion to densities. Shrimp density was defined as the number of individuals per $30 \mathrm{~min}$. The frequency of occurrence (FO) was used to classify species according to Dajoz (2000).

Before performing the comparison test, the normality of data was checked by the Kolmogorov-Smirnov test ( $p>0.05$ at all stations). The Mann-Whitney $U$-test was performed to compare densities between sampling sites using the STATISTICA 7.1 computer package. A significance level of $p<0.05$ was considered.

Correlations between environmental variables and taxonomic richness were tested by the Spearman correlation test. In order to study relationships between environmental variables and the structure and dynamics of the shrimp community, Canonical Correspondence Analysis (CCA) was performed based on the data matrix of shrimp densities. CCA is an ordination method effective in directly revealing correlations between the spatial structure of communities, and environmental factors that might be responsible for that structure (Ter Braak and Smilauer, 2002). Environmental variables and shrimp data were $\log _{10}(x+1)$ transformed prior to analysis. Monte Carlo permutations (500) were done so as to identify a subset of measured environmental variables, which exerted significant and independent influences on shrimp distribution at $p<0.05$. CCA was performed using CANOCO 4.5 (Ter Braak and Smilauer, 2002).

\section{RESULTS}

\section{> ENVIRONMENTAL VARIABLES}

The mean values of environmental variables are shown in Table I. The conductivity varied from $22 \mu \mathrm{S} \cdot \mathrm{cm}^{-1}$ (S1) to $61.5 \mu \mathrm{S} \cdot \mathrm{cm}^{-1}$ (S4). The water of Banco River was acid with low variation in $\mathrm{pH}$ (4.5 (S1)-6.1 (S3)) between sampling sites. It was the same for water temperature, which ranged between $25.87^{\circ} \mathrm{C}$ and $26.43^{\circ} \mathrm{C}$. The lowest dissolved oxygen values were recorded in permanent pools $\left(\leq 2.64 \mathrm{mg} \cdot \mathrm{L}^{-1}\right)$ and the highest values were observed in river channel stations $\left(\geq 4.12 \mathrm{mg} \cdot \mathrm{L}^{-1}\right)$. Generally, low turbidity $(\leq 13.15 \mathrm{NTU})$ was observed in upstream areas, while high values ( $\geq 30$ NTU) were recorded in the other sites. The upstream stations (S1 and S2) presented low values of velocity $\left(\leq 0.25 \mathrm{~m} \cdot \mathrm{S}^{-1}\right)$, while high values $\left(\geq 0.33 \mathrm{~m} \cdot \mathrm{S}^{-1}\right)$ were recorded in the middle and downstream stations (S3 and S5). In the permanent pools, width was almost constant, while it increased from upstream to downstream (2.77 to $4.61 \mathrm{~m})$ in the river channel. The depth in the study areas varied from $0.14 \mathrm{~m}$ (S1) to $0.48 \mathrm{~m}$ (S5).

\section{> COMPOSITION AND DISTRIBUTION OF SHRIMP SPECIES}

During this study, three shrimp species, Macrobrachium thysi, M. dux (Palaemonidae) and Desmocaris trispinosa (Desmocarididae), were collected. $M$. thysi and $D$. trispinosa were the species recorded in the upstream sites (S1 and S2). No shrimp was caught in the midstream station (S3). In the downstream station (S5), the three species were represented in samples, 
Table I

Environmental parameters evaluated in the study area. Cond.: conductivity, Temp.: temperature, DO: dissolved oxygen, Turb.: turbidity, S.D.: standard deviation, (-): not measured.

Tableau I

Paramètres environnementaux mesurés dans les sites d'étude.

\begin{tabular}{|c|c|c|c|c|c|c|c|c|c|c|}
\hline Stations & & Cond. & $\mathrm{pH}$ & Temp. & DO & Turb. & Velocity $(\mathrm{m} \cdot \mathrm{s}$ & Width (m) & Depth $(\mathrm{m})$ & Slope ( \\
\hline \multirow{3}{*}{ s1 } & Mean & 22.0 & 5.405 & 25.875 & 4.6 & 13.15 & 0.21 & 2.77 & 0.14 & \multirow{3}{*}{$45-90$} \\
\hline & Ranges & $20-24$ & $4.5-6.05$ & $25.3-26.7$ & $4.02-5.49$ & 11.9-14.3 & $0.20-0.23$ & $2.5-2.87$ & $0.13-0.15$ & \\
\hline & S.D. & 1.6 & 0.7 & 0.6 & 0.7 & 1.0 & 0.0 & 0.2 & 0.8 & \\
\hline \multirow{3}{*}{ S2 } & Mean & 26.0 & 5.3575 & 25.875 & 5.02 & 9.825 & 0.25 & 3.11 & 0.23 & \multirow{3}{*}{$45-90$} \\
\hline & Ranges & $22-36$ & $4.73-5.75$ & $25-26.5$ & 4.59-5.38 & $7.1-12.9$ & $0.22-0.3$ & $2.9-3.53$ & $0.20-0.26$ & \\
\hline & S.D. & 6.7 & 0.4 & 0.6 & 0.4 & 2.4 & 0.0 & 0.3 & 2.4 & \\
\hline \multirow{3}{*}{ S3 } & Mean & 45.0 & 5.62 & 26.43 & 4.12 & 43.9 & 0.45 & 3.66 & 0.28 & \multirow{3}{*}{$5-45$} \\
\hline & Ranges & $31-71$ & $5.25-5.97$ & $26.3-26.6$ & $4.06-4.22$ & $17.7-57$ & $0.38-0.54$ & 3.25-3.94 & $0.24-0.32$ & \\
\hline & S.D. & 22.5 & 0.4 & 0.2 & 0.1 & 22.7 & 0.1 & 0.4 & 4.1 & \\
\hline \multirow{3}{*}{ S4 } & Mean & 61.5 & 5.555 & 26.325 & 2.635 & 45.13 & - & - & - & \multirow{3}{*}{$<5$} \\
\hline & Ranges & $48-81$ & $4.96-5.9$ & $26.1-26.5$ & $1.4-3.8$ & $14.4-93$ & - & - & - & \\
\hline & S.D. & 15.9 & 0.4 & 0.2 & 1.0 & 42.0 & - & - & - & \\
\hline \multirow{3}{*}{ S5 } & Mean & 34.5 & 5.575 & 26.3 & 4.9775 & 30.03 & 0.33 & 4.61 & 0.48 & \multirow{3}{*}{$5-45$} \\
\hline & Ranges & $32-37$ & $5.12-6.05$ & $25.6-27.9$ & $4.56-5.6$ & $16.1-41$ & $0.30-0.38$ & $4.14-5.47$ & $0.38-0.66$ & \\
\hline & S.D. & 2.1 & 0.4 & 1.1 & 0.4 & 12.4 & 0.0 & 0.6 & 12.3 & \\
\hline \multirow{3}{*}{ S6 } & Mean & 36.5 & 5.3975 & 25.925 & 2.2325 & 48.47 & - & - & - & \multirow{3}{*}{$<5$} \\
\hline & Ranges & $32-40$ & $4.92-5.74$ & $25.6-26.2$ & $0.7-3.21$ & 16.4-104 & - & - & - & \\
\hline & S.D. & 3.4 & 0.4 & 0.3 & 1.1 & 48.3 & - & - & - & \\
\hline
\end{tabular}

whereas only $D$. trispinosa was captured in the permanent pool stations (S4 and S6). With the exception of the midstream station (S3), D. trispinosa was encountered in the other stations (Table I). Among the three shrimp species identified, M. dux was rare (FO $<25 \%$ ), M. thysi was common $(25 \%<\mathrm{FO}<50 \%)$ and $D$. trispinosa was very frequent (FO $>50 \%)$.

$D$. trispinosa $(67 \%)$ and $M$. thysi (32\%) represent more than $98 \%$ of the total number of individuals caught. The highest densities of $M$. thysi were observed in the upper stream stations (S1: 107 ind.30 $\mathrm{min}^{-1}$, S2: 86 ind.30 $\mathrm{min}^{-1}$ ). These densities were not significantly different between the upstream stations (Mann-Whitney $U$-test; $p>0.05$ ). For the other sampling areas, the highest density values were recorded for $D$. trispinosa (S4: 261 ind.30 $\mathrm{min}^{-1}$, S5: 183 ind.30 $\mathrm{min}^{-1}$, S6: 60 ind.30 $\mathrm{min}^{-1}$ ) (Table II). The Mann-Whitney U-test revealed significant difference (at least $p<0.05$ ) in $D$. trispinosa densities between sampling stations except for the upstream stations (S1 and S2).

\section{> RELATIONSHIPS BETWEEN ENVIRONMENTAL VARIABLES AND SHRIMP COMMUNITIES}

The Spearman correlation analysis indicated that Macrobrachium thysi was significantly influenced by conductivity, dissolved oxygen, turbidity, depth and mud (Table III). Width, depth and current velocity had a significant correlation with $M$. $d u x$. On the other hand, $D$. trispinosa was mainly influenced by current velocity, sand and gravel.

The results of redundancy analysis revealed that the relationships between the three shrimp species and their habitat conditions follow mainly the first two axes (Figure 2). These two axes accounted for $95.9 \%$ of the total variance and evidenced a spatial pattern in the shrimp assemblage of Banco River Basin. The midstream station (S3) where no shrimp was caught was excluded from analysis. The first axis (F1) opposed upstream stations in positive coordinates to permanent pools and downstream sites in negative coordinates. $M$. thysi and the other two species ( $M$. dux and $D$. Trispinosa) were also opposed according to the same interpretations. High densities of $M$. thysi were mainly influenced by a good oxygenation level, 


\section{Table II}

Density (individuals per 30 min), distribution of shrimp species in Banco River Basin study stations and results of the Mann-Whitney test. Med: median, Min: minimum, Max: maximum, (-): absence. Medians in the same column followed by different letters are significantly different $(p<0.05)$.

\section{Tableau II}

Densité (individus par $30 \mathrm{~min}$ ), distribution des espèces de crevettes dans les sites d'étude du bassin de la rivière Banco et résultats des tests de Mann-Whitney.

\begin{tabular}{|c|c|c|c|c|}
\hline \multirow[b]{2}{*}{ Stations } & & \multicolumn{3}{|c|}{ Shrimp species } \\
\hline & & Desmocaris trispinosa & Macrobrachium thysi & Macrobrachium dux \\
\hline & Med & $15^{\mathrm{a}}$ & $63.75^{\mathrm{a}}$ & - \\
\hline \multirow[t]{2}{*}{ S1 } & Min & 4.5 & 34.5 & - \\
\hline & Max & 45 & 106.5 & - \\
\hline & Med & $2.25^{\mathrm{a}}$ & $69^{a}$ & - \\
\hline \multirow[t]{2}{*}{ S2 } & Min & 1.5 & 21 & - \\
\hline & Max & 9 & 85.5 & - \\
\hline & Med & - & - & - \\
\hline \multirow[t]{2}{*}{ S3 } & Min & - & - & - \\
\hline & $\operatorname{Max}$ & - & - & - \\
\hline \multirow{3}{*}{ S4 } & Med & $208.5^{b}$ & - & - \\
\hline & Min & 120 & - & - \\
\hline & Max & 261 & - & - \\
\hline & Med & $122.25^{\mathrm{C}}$ & $0.5^{\mathrm{b}}$ & 3.75 \\
\hline \multirow[t]{3}{*}{ S5 } & Min & 66 & 0 & 0 \\
\hline & Max & 183 & 3 & 21 \\
\hline & Med & $34^{\mathrm{d}}$ & - & - \\
\hline \multirow[t]{2}{*}{ S6 } & Min & 10 & - & - \\
\hline & Max & 60 & - & - \\
\hline
\end{tabular}

\section{Table III}

Spearman correlation of shrimp densities and physicochemical data of Banco River Basin.

\section{Tableau III}

Corrélations de Spearman entre les densités de crevettes et les paramètres physico-chimiques dans le bassin de la rivière Banco.

\begin{tabular}{lcccccc} 
& \multicolumn{6}{c}{ Shrimp species } \\
\cline { 2 - 7 } & Macrobrachium thysi & Macrobrachium dux & Desmocaris trispinosa \\
\hline Environmental variables & $p$ & $\mathrm{r}$ & $p$ & $\mathrm{r}$ & $p$ & $\mathrm{n}$ \\
\hline Conductivity & $* *$ & -0.77 & $\mathrm{~ns}$ & 0.01 & $\mathrm{~ns}$ & 0.37 \\
pH & $\mathrm{ns}$ & -0.22 & $\mathrm{~ns}$ & 0.02 & $\mathrm{~ns}$ & 0.37 \\
Temperature & $\mathrm{ns}$ & -0.26 & $\mathrm{~ns}$ & -0.07 & $\mathrm{~ns}$ & -0.07 \\
Dissolved oxygen & $*$ & 0.44 & $\mathrm{~ns}$ & 0.38 & $\mathrm{~ns}$ & -0.35 \\
Turbidity & $* *$ & -0.76 & $\mathrm{~ns}$ & 0.12 & $\mathrm{~ns}$ & 0.21 \\
Current velocity & $\mathrm{ns}$ & 0.04 & $*$ & 0.41 & $* *$ & -0.54 \\
Width & $\mathrm{ns}$ & -0.3 & $* *$ & 0.65 & $\mathrm{~ns}$ & -0.19 \\
Depth & $* *$ & -0.75 & $*$ & 0.47 & $\mathrm{~ns}$ & 0.38 \\
Mud & $* *$ & 0.74 & $\mathrm{~ns}$ & 0.27 & $\mathrm{~ns}$ & -0.37 \\
Sand & $\mathrm{ns}$ & 0.33 & $\mathrm{~ns}$ & 0 & $* *$ & -0.64 \\
Gravel & $\mathrm{ns}$ & 0.03 & $\mathrm{~ns}$ & 0.39 & $* *$ & 0.61 \\
Woody debris & $\mathrm{ns}$ & 0.34 & $\mathrm{~ns}$ & -0.39 & $\mathrm{~ns}$ & 0.06 \\
Canopy & $\mathrm{ns}$ & 0.12 & $\mathrm{~ns}$ & -0.39 & $\mathrm{~ns}$ & 0.22 \\
\hline
\end{tabular}

r: Spearman correlation coefficient.

* or **: indicates significant difference ( $p \leq 0.05$ or 0.01$)$.

ns: non-significant relationship. 


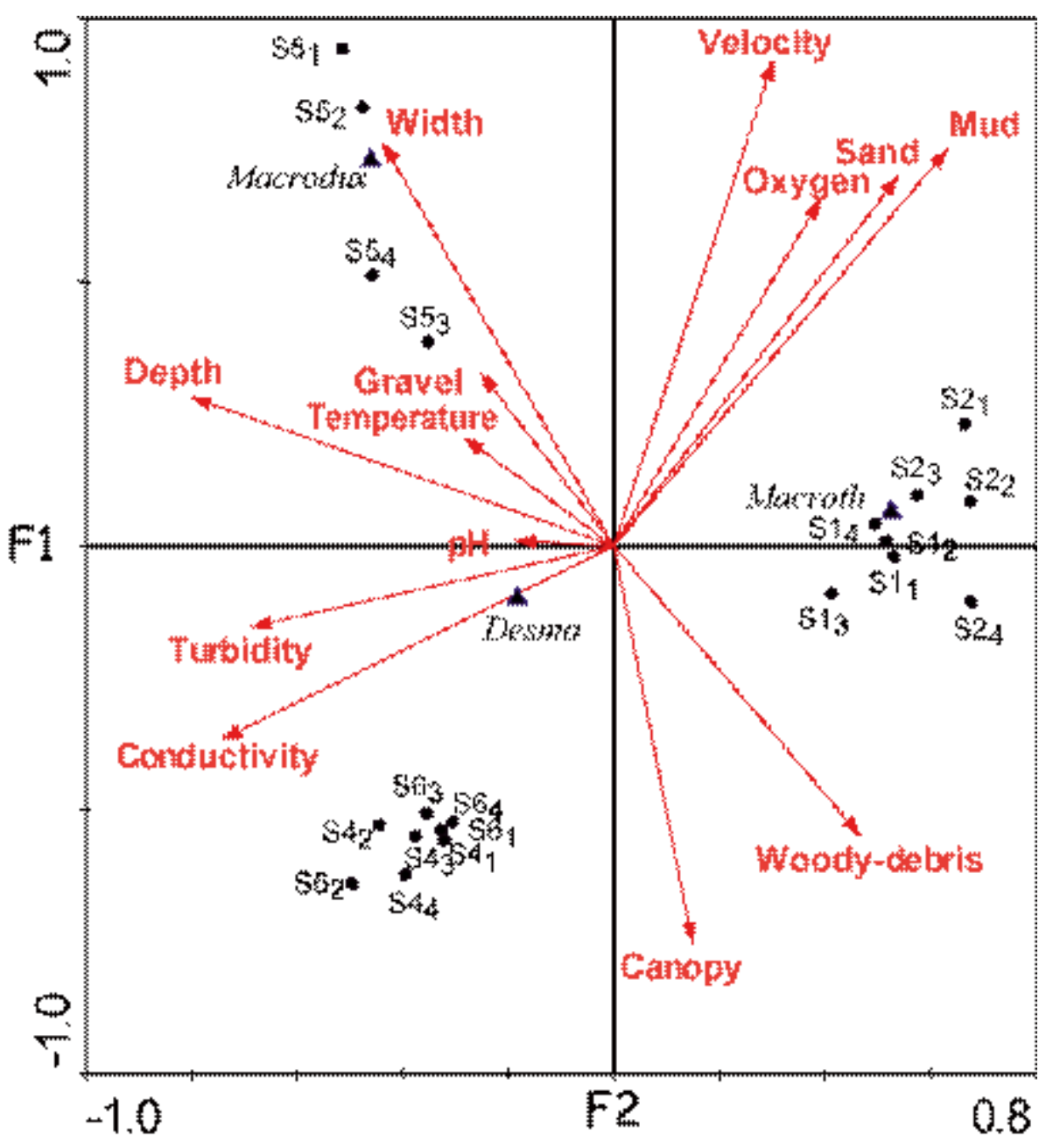

Figure 2

Canonical correspondence analysis triplot showing species and sampling stations in relation to environmental variables in Banco River Basin: Macrothysi = Macrobrachium thysi; Macrodux = Macrobrachium dux; Desmo = Desmocaris trispinosa; station (S); number of station (1-6); sampling period in indices (1 = May, 2 = September, 3 = October, 4 = February).

\section{Figure 2}

Analyse canonique des correspondances mettant en relation les espèces et les sites d'étude avec les variables environnementales dans le bassin de la rivière Banco. Macrothysi = Macrobrachium thysi; Macrodux = Macrobrachium dux $;$ Desmo = Desmocaris trispinosa; station (S) : numéro des stations (1-6); période d'échantillonnage (1 = mai, 2 = septembre, 3 = octobre, 4 = février $)$.

and high percentage of mud, sand and woody debris, while $M$. dux and D. trispinosa were more associated with high values of water depth, conductivity and turbidity. The second axis (F2) opposed the samples of downstream stations in positive coordinates to the samples from the permanent pools in negative coordinates. This axis also opposed $M$. $d u x$, which was influenced by high values of water width and current velocity, to $D$. Trispinosa.

\section{DISCUSSION}

This survey revealed that the number of shrimp species (3) recorded in the Banco River Basin is low compared with the diversity of other Ivorian rivers. Indeed, 7, 9 and 10 species were captured in the Bia (Gooré Bi, 1998), Boubo (N'Zi et al., 2008) and Mé rivers (N'Zi et al., 
2003), respectively. This difference in species richness was probably due to the rivers' sizes. In fact, Banco River is very small (9 km length, $4.5 \mathrm{~m}$ width) compared with Bia River (290 km, $150 \mathrm{~m}$ ), Boubo River (130 km, $13.54 \mathrm{~m}$ ) and Mé River (140 km, $13.48 \mathrm{~m})$ (N'Zi et al., 2003, 2008). Moreover, a previous study showed that from 1955 to 1998, Banco Bay lost more than $20 \%$ of its water surface to silting (Anoh, 2002). This comes from streaming waters that drain sometimes significant quantities of sand towards the bay, from free-bottomed gutters still numerous in the urban landscape of Abidjan. These sediments, which form a deposit in issues of the Banco River channel, create arrows of sand on which homeless populations settle down (Anoh, 2002). This deposit of sand constituted a barrier for the amphidromous shrimps (Macrabrachium vollenhovenii and $M$. macrobrachion) whose life cycles require upstream migration (Pyron and Covich, 2003; Benbow et al., 2004). The importance of species migration level as a determinant of species diversity and distribution is largely documented for tropical rivers (Hunte, 1977; Ville, 1983).

Macrobrachium thysi, an endemic species to Côte d'Ivoire (Powell, 1980), was commonly encountered in the upstream stations and absent in the middle stream and permanent pool stations. No shrimp specimen was collected in the middle stream station, while Desmocaris trispinosa was sampled in all the other sampling sites. It was the only one species registered in the permanent pool stations. Macrobrachium dux was found only in the downstream site.

This species distribution was related to the variation in habitat conditions in sampling sites. Several studies showed that the assemblages and distribution of the benthic macroinvertebrates, and their species richness, were usually extremely dependent on habitat heterogeneity (Fiévet et al., 2001; Able et al., 2002; Fossati et al., 2002; Arimoro et al., 2007, Bücker et al., 2008).

In the upstream sites, the shrimp assemblage of Banco River was dominated in number by $M$. thysi. The high density of $M$. thysi in upstream stations was due to a good oxygenation level and the presence of mud, woody debris and fragmented leaves. This microhabitat might offer favourable life conditions (substratum, food) for this shrimp. This observation corroborated the results of March et al. (2001), and Usio and Townsend (2001), which showed that crayfishes and shrimps are of fundamental importance to decomposition of plant material in streams. In addition, the high density of this species was observed in the sites presenting a low current velocity. This suggested that $M$. thysi has no ability to resist strong currents, as shown by Fossati et al. (2002) for Caridina waberi (Atyidae). D. trispinosa was more abundant in the downstream and permanent pool stations. This species seems to tolerate unfavourable conditions such as low dissolved oxygen and significant organic matter, as suggested by Cumberlidge (2005). It is well known that pools situated at a small geographical distance from one another tend to have similar macroinvertebrate assemblages (Briers and Biggs, 2005).

Macrobrachium dux was found only in the downstream site (S5). Its distribution was associated with high values of water depth and width, and current velocity. Due to its great size and strong pereiopods, $M$. dux is probably able to resist strong currents. This observation was in agreement with the results of Fossati et al. (2002) in Atyoida pilipes from Nuku-Hiva Island rivers.

Comparing $M$. thysi with $D$. trispinosa, our study revealed that the first species prefers clean water with good oxygen levels, while the second seems to tolerate low dissolved oxygen concentration. According to Rosenberg and Resh (1993), shrimps have different levels of sensitivity to pollution and many abiotic factors in the river ecosystem. Moreover, Declerck et al. (2005) reported that different taxonomic groups reacted differently in response to the same chemical parameters.

The poorer water quality downstream than upstream could be attributable to several maninduced activities such as urban runoff to surface river water due to direct or unregulated discharges in the Banco River of sewage water from neighbouring cities.

The absence of the shrimps at the middle stream station (S3) was related to regular point sources of pollution discharge due to the arrival of non-treated domestic sewage bringing about the water quality deterioration. Equally, the strong currents at this station explicated 
the absence of shrimp which cannot resist such currents. In other respects, the modification of the sandbank of the river bed by runoff at this station might justify the absence of shrimp. Our results indicated that the shrimp diversity was low (three species). The pattern distribution of these shrimps differs on a microhabitat scale. $M$. thysi required high oxygen and low current velocity, $D$. trispinosa tolerated a great variation in environmental conditions, while no factor influenced the distribution of $M$. dux. The middle stream areas of the Banco River, which received wastewater from some densely populated areas and industries nearby, sheltered no species. Thus, it is important that the regulatory authorities should implement and enforce an appropriate strategy to monitor, regulate and protect this area of the river and its community.

\section{ACKNOWLEDGEMENTS}

We are especially grateful to the "Office Ivoirienne des Parcs et Réserves" and the "Direction des Eaux et Forêts de Côte d'Ivoire" for the access permit to Banco National Park.

\section{REFERENCES}

Able K.W., Fahay M.P., Heck K.L., Roman C.T., Lazzari M.A. and Kaiser S.C., 2002. Seasonal distribution and abundance of fishes and decapod crustaceans in a Cape Cod estuary. Northeast. Nat., 9, 285-302.

Anoh K.P., 2002. Encombrement des baies de la lagune Ebrié : causes et impacts environnementaux. BIOTERRE, Rev. Inter. Sci. de la vie et de la terre, Nº́cial, 229-240.

Arimoro F.O., Ikomi R.B. and Iwegbue C.M.A., 2007. Water quality changes in relation to diptera community patterns and diversity measured at an organic effluent impacted stream in the Niger Delta, Nigeria. Ecol. Indic., 7, 541-552.

Benbow M.E., Burky A.J. and Way C.M., 2004. The use of two modified Breder traps to quantitatively study amphidromous upstream migration. Hydrobiologia, 527, 139-151.

Briers R.A. and Biggs J., 2005. Spatial patterns in pond invertebrate communities: separating environmental and distance effects. Aquat. Conserv., 15, 549-558.

Browder J.A., Gleason P.J. and Swift D.R., 1994. Periphyton in the Everglades: spatial variation, environmental correlates, and ecological implications. In: Davis S.M. and Ogden J.C. (eds.), Everglades: the ecosystem and its restoration, St. Lucie Press, Delray Beach, Florida, 445-460.

Bücker F., Gonçalves R., Bond-Buckup G. and Melo A.S., 2008. Effect of environmental variables on the distribution of two freshwater crabs (Anomura: Aeglidae). J. Crustacean. Biol. , 28, 2, 248-251.

Cumberlidge N., 2005. A rapid survey of the decapod crustaceans of the Boké Préfecture, Guinea. In: Wright H.E., McCullough J. and Diallo M.S. (eds.), A rapid Biological Assessment of Boké Préfecture, Northwestern Guinea Bulletin Biological Assessment, 41, 38-46.

Daget J. and Iltis A., 1965. Poissons de Côte d'Ivoire. Mémoire I.F.A.N., 74, 385 p.

Dajoz R., 2000. Précis d’Écologie, $7^{e}$ édition, Dunod, Paris, 615 p.

De Resende E.K., Pereira R.A.C., De Almeida V.L.L. and Da Silva A.G., 1996. Alimentaçao de peixes carnivoros da planicie inundavel do Rio Miranda, Pantanal, Mato Grosso do Sul, Brasileira de Pesquisa Agropecuaria, Centro de Pesquisa Agropecuaria do Pantanal. Boletim de Pesquisa, 3, $36 \mathrm{p}$.

Declerck S., Vandekerkhove J., Johansson L., Muylaert K., Conde-Porcuna J.M., Van Der Gucht K., Perez-Martinez C., Lauridsen T., Schwenk K., Zwart G., Rommens W., Lopez-Ramos J., Jeppesen E., Vyverman W., Brendonck L. and De Meester L., 2005. Multi-group biodiversity in shallow lakes along gradients of phosphorus and water plant cover. Ecology, 86, 1905-1915.

Fiévet E., Dolédec S. and Lim P., 2001. Distribution of migratory fishes and shrimps along multivariate gradients in tropical island streams. J. Fish Biol., 59, 390-402.

Fossati O., Mosseron M. and Keith P., 2002. Distribution and habitat utilization in two atyid shrimps (Crustacea: decapoda) in rivers of Nuku-Hiva Island (French Polynesia). Hydrobiologia, 472, 197206. 
Frederick P.C. and Spalding M.G., 1994. Factors affecting reproductive success of wading birds (Ciconiformes) in the Everglades ecosystem. In: Davis S.M. and Ogden J.C. (eds.), Everglades, The ecosystem and its restoration, St. Lucie Press, Delray Beach, Florida, 659-691.

Girard G., Sircoulon J. and Touchebeuf P., 1971. Aperçu sur les régimes hydrologiques. In: Avenard J.M., Eldin M., Guillaumet J.L., Adjanohoun E. and Perraud A. (eds.), Milieu naturel de la Côte d'Ivoire, Mémoire ORSTOM, 50, 109-155.

Gordon N.D., McMahon T.A. and Finlayson B.L., 1994. Stream Hydrology, an Introduction for Ecologists, Wiley \& Sons, New York, 526 p.

Gooré Bi G., 1998. Contribution à l'étude des crevettes d'eau douce de Côte d'Ivoire : systématique, biologie et analyse socio-économique de la pêche de Macrobrachium vollenhovenii (Herklots 1857) et de M. macrobrachion (Herklots 1851) (Crustacea Decapoda, Palaemonidae) du bassin de la Bia, Thèse de Doctorat $3^{\mathrm{e}}$ cycle, $145 \mathrm{p}$.

Hall J.B. and Swaine M.D., 1981. Distribution and ecology of vascular plants in a rain forest, Forest vegetation in Ghana, The Hague (Junk Publishers), $383 \mathrm{p}$.

Hunte W., 1977. Laboratory rearing of the Atyid shrimps Atya innocous Herbst and Micratya poeyi Guérin-Méneville (Decapoda, Atyidae). Aquaculture, 11, 373-378.

March J.G., Benstead J.P., Pringle C.M. and Ruebel M.W., 2001. Linking shrimp assemblages with rates of detrital processing along an elevational gradient in a tropical stream. Can. J. Fish Aquat Sci., $58,470-478$.

Monod T., 1966. Crevettes et crabes des côtes occidentales d'Afrique. In: Gordon I., Hall D.N.F., Monod T., Guinot D., Postel E., Hoestlandt H. and Mayrat A. (eds.), Réunion de spécialistes C. S. A. sur les crustacés, №77 Mémoires I.F.A.N., Zanzibar, Abingdon, Taylor \& Francis, 103-234.

Monod T., 1980. Décapode. In: Durand J.R. and Levêque C. (eds.), Flore et faune aquatiques de l'Afrique sahélo-soudanienne, Vol. I, 44, Paris, ORSTOM, 369-389.

N'Zi K.G., Gooré Bi G., N'Douba V., Koné T., Kouamélan E.P. and Ollevier F., 2003. Diversité biologique des crevettes d'un petit bassin côtier ouest africain, rivière Mé, Côte d'Ivoire en relation avec les variables environnementales. Sciences naturelles et agronomie, 27, 1-2, 17-27.

N'Zi K.G., Gooré Bi G., Kouamélan E.P., Koné T., N'Douba V. and Ollevier F., 2008. Influence des facteurs environnementaux sur la répartition spatiale des crevettes dans un petit bassin ouest africain rivière Boubo - Côte d'Ivoire. Tropicultura, 26, 1, 17-23.

Parren J.M.P.E. and De Graaf N.R., 1995. The quest for natural forest management in Ghana, Côte d'Ivoire and Liberia, Tropenbos, Series 13, Wageningen, $199 \mathrm{p}$.

Powell C.B., 1980. The genus Macrobrachium in West Africa, I: Macrobrachium thysi, a new large-egged species from the Côte d'Ivoire (Crustacea Decapoda Palaemonidae). Rev. Zool. Afr., 94, 317-326.

Pyron M. and Covich A.P., 2003. Migration patterns, densities, and growth of Neritina punctulata snails in Rio Espiritu Santo and Rio Mameyes, northeastern Puerto-Rico. Caribb. J. Sci., 39, 338-347.

Rios S.L. and Bailey R.C., 2006. Relationships between riparian vegetation and stream benthic communities at three spatial scales. Hydrobiologia, 553, 153-160.

Rosenberg D.M. and Resh V.H., 1993. Freshwater biomonitoring and benthic macroinvertebrates, Chapman \& Hall, New York, $488 \mathrm{p}$.

Ter Braak C.J.F. and Smilauer P., 2002. CANOCO reference manual and Canodraw for Windows user's guide: software for canonical community ordination (version 4.5), Microcomputer Power, New York.

Usio N. and Townsend C.R., 2001. The significance of the crayfish Paranephrops zealandicus as shledders in a New Zealand headwater stream. J. Crustacean. Biol., 21, 354-359.

Ville J.P., 1983. Influence de la salinité sur le déroulement des premiers stades larvaires des Macrobrachium vollenhovenii (Herklots 1851). Décapode, Palaemonidae. Ann. Univ. Abidjan, Ser. E (Écologie), 4, 325-341. 